\title{
The Sabbath, the Synagogue, and Leisure Culture: Jewish Tradition and Modernity
}

\begin{abstract}
Nitza Davidovitch, Aryeh Lazar
Ariel University, Ariel, Israel

In this paper, we focus on the unique concept of the "Sabbath" (the Lord's Day) as a period of leisure in modern Israel and its features in terms of duration, activity, state of mind, and Jewish values. Against this backdrop, we discuss the functions that the synagogue continues to play in leisure culture in Israel, especially on the Sabbath. Synagogues enhance the significance of the Sabbath as a time of leisure, constitute a site of leisure activity, and promote leisure as a state of mind and a value in itself. Judaism has many faces, and this diversity is an integral part of the population's approach to leisure and its leisure practices. This article focuses on the orthodox Jewish concept of leisure, and may shed light on attitudes and practices of members of other religions that consider God's work the focal point of human life.
\end{abstract}

Keywords: Sabbath, synagogue, leisure culture, Jewish tradition, modernity

\section{Introduction}

The biblical commandment to observe the Sabbath ${ }^{1}$, one of the 10 commandments handed down to Moses at Mt. Sinai is a practical expression of God's actions after completing the creation in six days. In Judaism, the Sabbath symbolizes the creation of the world by God, and the distinction between the sacred and the profane - in terms of time, action, and state of mind - where the desire to transform the profane into the sacred is a value in itself (Poel, 2006). The Sabbath is not perceived on the basis of the non-action that characterizes it, but rather as the climax of spiritual activity, where everyday activities gain a unique expression through the sacred and pleasurable study of Torah and the accompanying spiritual uplifting on the Sabbath. Observing the Sabbath is a practical and principled acknowledgement of the creation of the world and faith in its creator and the observance of the Sabbath is considered a spiritual state in which the individual becomes closer to the creator. Already in ancient times, did other nations adopt the basic idea underlying the Sabbath as a weekly day of rest, and in modern times, this concept promoted various socialist doctrines to shorten the working day and week. In Israel, Saturday is an official day of rest.

\section{The Jewish Sabbath}

The Sabbath infuses the Jewish concept of time through a distinction between the sacred and the mundane. The beginning of the Sabbath is the end of Friday (before sunset), and the Sabbath ends on the next evening when stars appear in the sky. Since the Sabbath is a manifestation of the sacred, it separates sanctity from the

Nitza Davidovitch, Ph.D., professor, Department of Behavioral Sciences \& Psychology, Ariel University.

Aryeh Lazar, Ph.D., senior lecturer, Department of Behavioral Sciences \& Psychology, Ariel University.

${ }^{1}$ Genesis 2, pp. 1-3. 
mundane (Ne'eman, 2008). At the conclusion of the Sabbath, observers traditionally wait several minutes after the first three stars being observed before proceeding to perform mundane activities, to stress that observance is not a burden and is not "shaken off" immediately when the law permits this. The religious Sabbath has a fixed essentially sacred schedule from beginning to end. For example:

1. Lighting the Sabbath candles-The Sabbath opens with the lighting of the Sabbath candles and a blessing, before sunset on Friday. Lighting the candles is considered a commandment that is designed to create a pleasant home atmosphere and induce a sense of peace, among other things. Traditionally, the woman of the household lights and blesses the candles, which ushers in the Sabbath.

2. Kabalat Shabat-The Sabbath prayer begins with selected hymns from Psalms, which is a relatively recent ritual developed in Zefat in the 16th century by Kabbalists, together with the song "Lecha Dodi," spread from there to Jewish communities throughout the diaspora.

3. Kiddush-Kiddush is a ceremony performed before the beginning of Friday night dinner, in the presence of all the members of the household, and it includes a blessing that is recited over a cup of wine on Friday night and on Saturday.

4. Sabbath prayers-The festive morning prayer read the weekly Torah portion, another readings, and prayers. Reading a different portion of the Torah on every Sabbath in synagogue is an ancient Jewish tradition.

5. Sabbath meals - Sabbath observers are commended to partake in the three Sabbath meals include delicacies that are not typically eaten on weekdays (Midrash Tanhuma). These three meals are consumed on Friday night, Saturday morning, and Saturday afternoon. The commandment to partake in this extra meal in the afternoon stems from the commandment to partake in pleasurable activities on the Sabbath, to honor the Sabbath more than ordinary weekdays. In each Sabbath meal, a blessing is recited on two challahs and these meals typically include meat, fish, and other special delicacies. Zemirot (Sabbath hymns) are sung at these Sabbath meals.

6. Havdala - This ritual symbolizes the end of the Sabbath, and it is designed to separate the sacred from the mundane, from the Sabbath and the weekdays. It is only after havdala that people may engage in their regular weekday's activities that are prohibited on the Sabbath.

Observing the Sabbath demands that individuals refrain from performing all the activities that are specifically prohibited. Jewish communities in Europe and the United States typically devote the Sabbath to family or social-cultural activities in the community, while Sunday is devoted to social activities that involve non-Jewish acquaintances.

The Sabbath is an enclave of serenity in the whirlwind of work, anxieties, struggle, and adversity that characterize the everyday life and the other days of the week. On the Sabbath, for 25 hours, the world figuratively stands still: Businesses are closed, cars remain in the driveway, the telephone stops ringing, computers, radio, and television are off, and the pressure and concerns of material life withdraw behind a veil of oblivion. When we stop all our productive involvement in the physical world, our mind turns inward to family and friends, to our inner selves, and to our souls.

\section{The Sabbath as a Time of Leisure}

On the modern conception of time, leisure is a psychological and spiritual state of mind. According to the modern conception of time, leisure is freedom of obligations, the time remaining to the individual after completing all the activities required for existence - eating, sleeping, learning, and working (Davidovitch, 2014). Leisure is considered as a type of mental experience or state in which a person is free of external 
obligations on his/her time or activities. On this view, the person is free of internal binds or restrictions, and is a free person. This is the essence of the Sabbath (Davidovitch, 2014). However, on the Sabbath, we recall that the world is not ours to do with as we please. The world is the creation of God. We are in a state of faithful consciousness. When we refrain from work on the 17th day, we follow the example of the creator, confirm that God created the world in six days, and assimilate this acknowledgement into our consciousness. Furthermore, on the Sabbath, we connect to the idea of freedom, recalling how God took us out of Egypt and determined that we would never be slaves to any foreign master. We remember that our work, our financial obligations, and our engagement in material matters are not the masters of our lives and they are merely the tools through which we realize our spiritual purpose (Arie, 2014).

The modern conception of time also addresses leisure as a value in itself, a time during which one may engage in activities or acquire skills related to moral development, which have implications for the behavioral norms of individuals in society. Leisure not only takes place in the private realm of the individual, but also in the social realm, and it is driven by intrinsic reward, pleasure, and personal satisfaction rather than the desire to attain external benefits (Davidovitch, 2014).

This is also true of the Sabbath. Throughout Jewish history, the Sabbath was a fundamental and focal value in Judaism. The commandment to observe the Sabbath as a day of rest and abstention from work was handed down to man at his creation, and to the Jewish nation at Mt. Sinai, as the fourth of the 10 commandments ${ }^{2}$.

\section{The Universality of the Sabbath}

When the Mishna was written, the sages recorded debates related to the Sabbath. In tradition and legends, the Sabbath is described as the day on which the entire universe rests, including animals, vegetables, and non-living things. It is recounted that when the nation of Israel was in the desert, the manna did not appear on the Sabbath, and the people were given a double portion for the Sabbath on Friday. Also, the animals, plants, and even realms are described, such as hell, that refrain from deliberate activity on the Sabbath, while other entities awaken, such as the tree of life, all souls, or the divine spirit (Shekinah), that enters our world from the coming world on the Sabbath.

The value of Sabbath observance and its separation from weekdays has several aims:

1. To recall the creation and institute a day of absolute rest. The commandment to remember and observe the Sabbath brings people closer to God through engaging in an activity that is similar to the creator, and discovering the spirit of God and their purpose inside themselves (Marsden, Reed, Kennedy, \& Stinson, 1982).

2. To mark the exodus from Egypt: To entrench the memory of the Jewish nation's exodus from Egypt, in order to reinforce faith in divine salvation and to compel everyone to act toward others with charity and justice ${ }^{3}$.

3. A day of rest as a righteous act with social implications: Instituting a day of rest in order to improve the condition of man and the foundation of the Sabbath is human freedom. On the Sabbath, no man controls another and all are equal before God. The Sabbath also addresses the liberation of animals and plants that serve mankind and the entire universe: All slaves and beasts of burden who serve man, and all trees planted for the benefit of man, rest on the Sabbath.

\footnotetext{
2 Exodus 20, p. 8.

${ }^{3}$ Numbers 5, pp. 12-15.
} 
4. Affirmation of the covenant between God and the people of Israel: As one of the 10 commandments, Sabbath observance is a fundamental part in the affirmation of the covenant between God and his people on Mt. Sinai, and a reminder of their status as the chosen people ${ }^{4}$.

5. The Sabbath as the source of spiritual significance: The Sabbath grants meaning to all the days of the year. For people who are able to apprehend the sanctity of the Sabbath and allow it to uplift them, experience the sanctity of the Sabbath throughout the entire week. These ideas also influenced Sabbath customs of the Hassidim and Kabbalists, promoting their efforts to extend the Sabbath even beyond its traditional conclusion.

6. The Sabbath as a symbol of Jewish identity: The Sabbath has been and remains one of the many powerful ways to realize Jewish belonging and convey Judaism to our children and the future generations, anywhere, and under the harshest conditions.

7. The Sabbath is pleasure: The Sabbath is delicious food, an abundant, beautifully set table, candle lights, pleasant song, and pleasant sleep. On the Sabbath, the body and the soul are together elevated to higher realms of spirituality, and the Sabbath pleasures of food and drink are an act of God.

8. The Sabbath is spirituality. The Sabbath is the "soul" of the entire week. Sabbath blessings flow throughout the coming week to all who observe it. Observing the Sabbath guarantees that God blesses our success in the coming week, and imbues the week with a sense of purpose and meaning.

9. The Sabbath is a taste of the next world to come: The Sabbath is our weekly taste of this future world to come.

In summary, a review of the concept of the Sabbath in Jewish sources indicates that the Sabbath is genuine leisure, even in terms of concept of leisure in the modern 21st century. On the Sabbath, the means (freedom and pleasure) converge with man's purpose and meaning in this world. The mundane (time, activities, state of mind, and values) and the sacred are fused, elevating the mundane to a degree of sanctity (Arie, 2014).

\section{The Synagogue}

The synagogue ("Beit Knesset"- literally — the house of assembly) is the Jewish house of prayer and is known by this name as it is a place where the congregation assembles. Jews customarily pray three times a day, with additional prayers on the Sabbath, the first day of each new month and on holidays. The synagogue is traditionally the site of public prayers: A quorum of 10 adult males (at the ages of 13 and over) is required for a prayer to be considered a public prayer. The idea behind the quorum is that even a small group of Jews represents the entire Jewish people. The quorum thus serves as the conceptual foundation that represents the autonomy of the community and congregation. Prayers are led by the cantor, considered the "public representative."

Although all synagogues are open to all Jews, synagogues are typically distinguished by sect (due to the different versions of prayer: Ashkenazi, Sephardi, Yemenite, etc.) and by their stream (orthodox, conservative, reform, etc.). The synagogue plays many important roles in the lives of its congregants, from a place of prayer, to a site of culture, a place where congregants assemble to discuss public matters, such as charity and mutual assistance, and a place of Torah learning. In the Middle Ages, the synagogue also served as a place of learning for the entire community, and contained a library of texts related to Torah learning. In fact, the study of Torah in a synagogue is considered to have a special merit, even above study in a beit Midrash.

${ }^{4}$ Ezekiel 2, p. 12. 


\section{The Structure of the Synagogue}

A women's gallery was set up in order to encourage women to come to prayers. The women's gallery was a separate area or space, separated by a curtain or a divider, where the women sat and participated in the prayers. Congregants would seek advice on Jewish law at the entrance to the synagogue or in the yard, and rabbis would announce their decisions of legal cases that they heard concerning interpersonal issues. These additional functions added to the major role that the synagogue played in Jewish life, both in the spiritual life of the community and its administration.

Although Jewish law does not define guidelines for the structure of a synagogue, several principles are traditionally implemented in all Jewish synagogues: The Torah Ark is the receptacle or closet used to store Torah scrolls and other sacred objects. Typically, the Ark is located on a raised platform. The synagogue functions as the house of prayer on weekdays, the Sabbath, and holidays. The synagogue is the site of community rituals and ceremonies, such as reading the Meggilah on Purim or the festivities on Simhat Torah. The synagogue is also the site of significant personal ceremonies that commemorate rites of passage, such as circumcision, bar mitzvah, bat mitzvah, weddings, and memorials. As a result, the synagogue is both a religious and a community center.

\section{Functions of the Sabbath}

In modern Judaism, the synagogue has two main functions on the Sabbath. The first function focuses on the religious ritual of prayer. On the Sabbath, the prayers recited are longer than are those recited on weekdays in part due to the fact that since individuals have more leisure time to spend in the synagogue. In addition to the regular morning service, a weekly portion of the Torah is publicly read and an additional prayer is also recited. Therefore, while in weekday's morning, prayer services usually take between 40-60 minutes, in the Sabbath morning, prayers take between two and three hours. However, on weekdays and the Sabbath, prayers differ not only in scope but also in content. On weekdays, prayers focus on the prayer's requests of God to fulfill his/her needs - both physical as well as spiritual. In contrast, on the Sabbath, an individual is prohibited from praying for his/her needs. Rather, the prayers on the Sabbath focus on praising God. In addition, during the week, prayer is very individualized. Although the prayers are preferably recited in the synagogue in a quorum of 10 , and are said by all participants concurrently, each prayer says his/her prayers separately, and on the weekday, prayer service assumes the nature of individual prayers. However, on the Sabbath, the prayers have a more communal and public flavor. The leader of the services chants many portions of the prayer in a manner that ensures that all pray at the same pace. Many of the specific prayers sing together by all participants using traditional melodies or by adapting modern music to the prayers. In this way, the three "ABC" aspects of prayer -affective, behavioral, and cognitive - differ on the Sabbath and are more conducive to the more leisurely climate of the Sabbath (Frankel, 1981).

The second function of the synagogue on the Sabbath is that of a communal meeting place. Whereas in many synagogues during the week, morning services are held at a number of different hours in accordance with a variety of needs to reach work on time, on the Sabbath, there is often only one service that starts at a much later hour than is customary during the week. In addition, during the week, even very religious women usually do not attend prayer services in the synagogue. Instead, they pray in a more private manner within the confines of their own homes. In contrast, on the Sabbath, the women's section in orthodox synagogues is usually full 
both on Sabbath eve as well as on Sabbath morning. Accordingly, in many synagogues at the conclusion of the Friday night services, one of the lay leaders of the synagogue often gives a series of communal announcements concerning the events of the passing week: (a) congratulations for engagements and weddings; (b) consolations for mourners; (c) welcome to newcomers to the community and farewell to those who are leaving; and (d) announcements regarding various religious and social functions, such as Torah classes and charity functions. In some synagogues, the lay leader requests the congregation to be seated since these announcements may take quite some time. Whereas on weekdays individuals often hurry out of the synagogue at the conclusion of the prayers, on the Sabbath, it is common for most people to remain until the service is completely concluded and then, after leisurely exiting the synagogue, most people congregate outside for conversation, to catch up on community events (and discuss politics).

Therefore, in this manner, the entire "synagogue experience" on the Sabbath is very different from that on weekdays. Whereas during the week the synagogue has a more instrumental function as a place of more individualized worship, on the Sabbath the communal aspects are much more salient both for the more ritualistic aspects as well as for the more social aspects.

\section{Summary and Discussion}

This chapter discusses the traditional Jewish conception of the Sabbath as a manifestation of ideal leisure, in terms of time, activities, state of mind, and traditional religious value.

According to Jewish sources, the Sabbath is the ultimate manifestation of leisure, the time in which God's presence is felt more powerfully than at any other time during the week. The Sabbath is a spiritual time- - a time of sanctity. The stability and regularity of the Sabbath transcend limitations of time and place. The Sabbath is also the litmus test of whether a person or family will remain a living, breathing part of the Jewish nation. The Sabbath is a powerful opportunity to connect to God and to freedom.

Judaism teaches that the body may be elevated to a state of sanctity. Even in the modern era, there are spiritual methods that acknowledge the conflict between flesh and spirit, and between body and soul. In Judaism, the body is man's tool for a spiritual journey in life, and this journey should have some expression in the education system.

Sanctity is a concept that relates to the spiritual and transcendent, it represents the opposite of the mundane. The phrase "Holy Sabbath" implies that the Sabbath is holy. We perform Kiddush to sanctify the Sabbath. The root "k-d-s" means to designate something for a specific purpose and to distinguish it from other aims or purposes by doing so. Respect and tolerance for all conceptions of the sacred and the mundane should be taught within leisure education.

The Sabbath has many aspects and is one of the main pillars in the Jewish worldview. Over generations, the Sabbath was based on two foundations: rest and sanctity. The singularity of the Jewish Sabbath was traditionally reflected in rest from the work of the week and in the instilment of a dimension of spirituality, both dimensions embodied through the synagogue. The weekly transition from the profane to the sacred, from work to rest, is likened to the transition from slavery to freedom, to leisure, and to God's version of leisure, which is engagement in prayer and song, family and friends, and serenity and peace. The synagogue and the Sabbath combine both old and new. In both, leisure is an aim, manifest in the contrast between sanctity and the mundane. The challenge of our generation is how to preserve this dimension of leisure in our fast-paced technology-intense world. 
There is a long and complicated history of factors that have influenced the local culture in Israel over generations. Over the long history of the Jewish people, the importance of leisure and its role in Jewish life has been a recurring question. Should a hedonist lifestyle be adopted, following Aristophanes in the fifth century $\mathrm{BC}$, for whom pleasure was a supreme value, or should a later approach be adopted, that of utilitarianism, that was developed in the eighteenth century, based on the argument that instead of expanding the quantity of pleasures, a person should expand the types of pleasures and should assess them qualitatively as well (Mill, 2006).

\section{Conclusion}

We find that in the modern era, leisure is a legitimate pursuit. In the past, when traditional thinking was dominant, leisure was considered an illegitimate activity, associated with idleness. Today, leisure is considered a legitimate pursuit. The question is no longer whether to devote time to leisure, but how to spend leisure time, which underscores the importance of leisure education policy development for society as a whole. What are needed are programs that leverage leisure time for personal empowerment.

We live in an era in which leisure is one of the most quintessential indications of modern society. Leisure is enjoyed by all, religious and non-religious populations. It can be said that the concept of leisure constitutes a milestone in the human economic and social development, yet holds challenges and risks for the orthodox Jewish sector. Leaders of the future and educators in this sector will be required to address these challenges, including the following aspects:

1. Awareness: Engagement in various activities during leisure hours has a unique quality that one should know how to exploit and gain maximum benefit;

2. Individual responsibility: The understanding that leisure activities are one's own responsibility and one should know how to use leisure time as he/she sees fit;

3. Identifying the talents in each individual, and consulting with professionals who are experts in leisure and recreation;

4. Information: Collecting extensive, up-to-date information on the types of activities that appeal to people, their costs, locations, settings, and conditions;

This article focuses on the orthodox Jewish perspective on leisure, and may shed light on the leisure attitudes and practices of other religions that consider God's work the core of human life.

\section{References}

Arie, R. (2014). Leisure and life of the Ultra-Orthodox in Israel. In M. Leitner, \& S. Leitner (Eds.), Israeli life and leisure in the 21 st century (pp. 240-252). Urbna, I.L.: Sagamore.

Davidovich, N. (2014). A multicultural concept of leisure in 21st century Israel-tradition and modernity. In M. Leitner, \& S. Leitner (Eds.), Israeli life and leisure in the 21st century (pp. 393-402). Urbna, I.L.: Sagamore.

Frankel, I. (1981). The culture of leisure as perceived by Judaism. In O. Mashiach, C. Spector, \& A. Ronen (Eds), Educating for leisure (pp. 16-20). Ra'anana: Mofet Institute.

Mill, J. S. (2006). On liberty (Original work published in 1859). (A. Amir, Trans.). Jerusalem: Shalem.

Marsden, P. V., Reed, J. S., Kennedy, M. D., \& Stinson, K. M. (1982). American regional cultures and differences in leisure time activities. Social Forces, 60(4), 1023-1049.

Ne'eman, N. (2008). Leisure as the reasons for relinquishing a religious life style-Indeed? Megamot, 45, 743-764.

Poel, H. V. D. (2006). Sociology and cultural studies. In C. Rojek, S. M. Shaw, \& A. J. Veal (Eds.), A handbook of leisure studies (pp. 93-108). Basingstoke, U.K.: Palgrave-Macmillan. 